\title{
Human polyomavirus JC replication and non-coding control region analysis in multiple sclerosis patients under natalizumab treatment
}

\author{
Valeria Pietropaolo ${ }^{1,2}$ - Anna Bellizzi ${ }^{3,4}$ - Elena Anzivino ${ }^{1}$ Marco Iannetta ${ }^{5}$. \\ Maria Antonella Zingaropoli ${ }^{1}$ Donatella Maria Rodio $^{1}$ - Manuela Morreale ${ }^{6}$. \\ Simona Pontecorvo ${ }^{7} \cdot$ Ada Francia $^{8}$ • Vincenzo Vullo ${ }^{1}$. Anna Teresa Palamara ${ }^{3,9}$. \\ Maria Rosa Ciardi ${ }^{1}$
}

Received: 12 December 2014 / Revised: 10 March 2015 / Accepted: 24 March 2015 /Published online: 1 May 2015

(C) The Author(s) 2015. This article is published with open access at Springerlink.com

\begin{abstract}
In the last years, the treatment of multiple sclerosis (MS) patients with natalizumab has been associated with the occurrence of progressive multifocal leukoencephalopathy (PML) caused by human polyomavirus JC (JCV). Here, we have shown a significant correlation between patients with JC viruria and positive JC-specific antibody response and patients without JCV-specific antibodies after 1 year of natalizumab $(p=0.0006)$. Furthermore, JCV-specific quantitative PCR on urine and plasma samples, collected at the enrollment (t0) and every 4 months ( $\mathrm{t} 1, \mathrm{t} 2, \mathrm{t} 3)$ in the first year and at two time points ( $t 4$ and $t 5)$ in the second year of natalizumab treatment, indicated the prevalence of JC viremia rather than $\mathrm{JC}$ viruria only in the second year of treatment $(p=0.04)$. Moreover, the analysis of JCV non-coding control region (NCCR) sequences in peripheral blood mononuclear cells of patients with JC-specific antibodies after 12 natalizumab infusions $(\mathrm{t} 3)$ revealed the presence of rearranged sequences, whereas the prevalence of genotypes $1 \mathrm{~A}, 1 \mathrm{~B}$, and 4 was detected in these patients by VP1 sequence analysis. In
\end{abstract}

Valeria Pietropaolo and Anna Bellizzi contributed equally to this work.

Valeria Pietropaolo

valeria.pietropaolo@uniroma1.it

1 Department of Public Health and Infectious Diseases, Sapienza University of Rome, P.le Aldo Moro, 5, 00185 Rome, Italy

2 Sbarro Institute for Cancer Research and Molecular Medicine, Center for Biotechnology, College of Science and Technology, Temple University, Philadelphia, USA

3 Department of Public Health and Infectious Diseases, Institute Pasteur, Cenci-Bolognetti Foundation, Sapienza University of Rome, Rome, Italy summary, JC viruria evaluation seems to be useful to identify early those patients who do not already develop a humoral immune response against JCV. It may also be interesting to study the JCV NCCR rearrangements since they could give us new insights on the onset of neuro-invasive viral variants.

Keywords Polyomavirus JC · Multiple sclerosis · Natalizumab · STRATIFY JCV ${ }^{\circledR} \cdot$ Real-time PCR .

NCCR sequencing

\section{Introduction}

In the last years, many immune-mediated diseases such as multiple sclerosis (MS) have been managed using biological drugs. Nevertheless, the use of these drugs was soon associated with the onset of progressive multifocal leukoencephalopathy (PML). In 2005, two patients with MS (KleinschmidtDeMasters and Tyler 2005; Langer-Gould et al. 2005) and

4 Department of Neuroscience, Temple University School of Medicine, Philadelphia, USA

5 Institut Cochin, Inserm U1016, Equipe Physiologie des cellules dendritiques, Paris, France

6 Department of Medico-Surgical Sciences and Biotechnologies, Section of Neurology, Sapienza University of Rome, Rome, Italy

7 Istituto di Ricerca e Cura a Carattere Scientifico-Neuromed, Pozzilli, Isernia, Italy

8 Multiple Sclerosis Center, Department of Neurology and Psychiatry, Sapienza University of Rome, Rome, Italy

9 San Raffaele Pisana Scientific Institute for Research, Hospitalization and Health Care, Rome, Italy 
one with Crohn's disease (CD) (Van Assche et al. 2005) were reported as the first cases of PML development after the treatment with natalizumab (Tysabri ${ }^{\circledR}$, Biogen Idec, Elan Pharmaceuticals). PML is a demyelinating disease of the central nervous system (CNS) caused by polyomavirus JC (JCV) lytic infection of oligodendrocytes. JCV is a DNA neurotropic virus isolated in 1971 from the brain of a patient with PML (Padgett et al. 1971). Ninety percent of the worldwide adult population has antibodies against JCV, with $27 \%$ of healthy individuals that asymptomatically release virions in the urine (Brew et al. 2010; Kean et al. 2009). The early and the late coding regions of JCV genome are highly conserved and can be associated with viral genotypes and subtypes of specific geographical areas (Agostini et al. 2001). In contrast, the viral non-coding control region (NCCR) is highly variable and characterized by determinants of neurotropism and neurovirulence. Rearranged NCCR sequences were observed during the host immunosuppression, and they correlated with a poor prognosis in PML patients. The incidence of PML has increased during the global HIV epidemic in the 1980s (Tan and Koralnik 2010), although the introduction of combination antiretroviral therapy (cART) in the treatment of HIV infection has overturned this trend, with a reduction of PML onset among HIV patients. However, in recent years, PML cases are increasing among patients with immune-mediated diseases treated with monoclonal antibodies (mAb) (Weissert 2011), and as of January 2015, 514 cases of PML had been reported among the 132,600 MS patients treated with natalizumab worldwide, with a fatality rate of about 20-25\% (TYSABRI Safety Update 2015). The estimated risk of natalizumab PML-associated is 11.1 cases per 1000 patients ( $95 \%$ CI 8.3 to 14.5 ) when the three main risk factors are present: (1) JCV-specific antibodies, (2) previous use of immunosuppressants, and (3) 25 months of natalizumab treatment (Bloomgren et al. 2012; Sørensen et al. 2012). Natalizumab interferes with lymphocyte trafficking through the blood-brain barrier (BBB) by blocking the interaction of very late antigen 4 (VLA4) with adhesion molecule type 1 on vascular cells (VCAM-1). This blocking seems to result in decreased immunosurveillance and JCV reactivation from latency (Berger and Houff 2009; Tan et al. 2010; Zohren et al. 2008). To date, specific biomarkers of PML risk assessment are not available and no correlation has been reported between the JC viral load in blood and/or urine and the PML onset (Andreoletti et al. 2002; Marzocchetti et al. 2009; Rudick et al. 2010; Tan et al. 2010). However, a new enzyme immunoassay (STRATIFY JCV ${ }^{\circledR}$ ) has been distributed by the same pharmaceutical company producing natalizumab to discriminate JCV-specific serostatus (Gorelik et al. 2010) and viral DNA detection in urine samples has been found useful for a more accurate stratification of PML risk in patients treated with natalizumab (Laroni et al. 2012). In fact, it has been suggested that JCV viruria could allow identification of JCV-positive patients with undetectable JCV-specific antibodies (Mancuso et al. 2012). Nevertheless, the exact mechanism by which natalizumab promotes the PML pathogenesis has not yet been well defined, but it strongly depends on a reduced immune surveillance of the central nervous system (Coisne et al. 2009; Kivisakk et al. 2009; Stuve et al. 2006). Despite the JCV lytic infection of oligodendrocytes in individuals with PML, JCV can latently persist in a variety of cell types including hematopoietic precursor CD34+ cells and B cells in the bone marrow, brain, tonsils, and the bloodstream (Marzocchetti et al. 2009; Tan et al. 2010). It is also important to note that the development of PML in immunocompromised patients appears to be limited to rearrangements of the viral NCCR and the consequent enhancing of viral gene expression mediated by the binding of specific cellular transcription factors on the JCV NCCR (Marshall and Major 2010). Therefore, in this study, we have investigated the trend of JCV replication in cohorts of relapsing-remitting MS (RRMS) patients at a different stage of natalizumab treatment: at the baseline with the number of natalizumab infusions equal to $0(\mathrm{t} 0)$, during the first 12 infusions ( $<12$ months), and after more than 12 months of treatment ( $>12$ months). Three aspects of JCV replication have been evaluated: (1) the monitoring of JCV viral load by real-time quantitative PCR (Q-PCR) in different biological samples collected from the cohort at specific sampling times; (2) the analysis of possible rearrangements of the JCV NCCR, in order to identify possible mutations in the binding sites for specific transcription factors; and (3) the sequence analysis of the JCV VP1 gene, in order to establish a possible correlation between a specific JCV genotype/subtype and patients with RRMS treated with natalizumab.

\section{Materials and methods}

\section{Features of enrolled patients and study schedule}

Patients affected by RRMS, referred to the Department of Neurology and Psychiatry of the University of Rome "Sapienza" from March 2012 to March 2014, and with the following number of infusions of natalizumab, have been enrolled:

- Twenty-two patients (mean age \pm stand. dev. 30.6 \pm 6.8 ; mean months of illness \pm stand. dev. $84 \pm 85.7$; mean Expanded Disability Status Scale (EDSS) \pm stand. dev. $1.9 \pm 1.3)$ were enrolled before treatment with natalizumab ( $\mathrm{t} 0$ : baseline or 0 infusions) and a total of 22 samples of whole blood in EDTA and 22 urine samples have been collected. Of these 22 patients, 2 had discontinued therapy for allergic reaction to the biologic after 2 natalizumab infusions and 5 showed poor compliance (Table 1). The remaining 15 patients (mean age \pm stand. dev. $33 \pm 7.7$; mean months of illness \pm stand. dev. 
Table 1 Clinical features of RRSM patients

\begin{tabular}{|c|c|c|c|c|}
\hline & \multirow[t]{2}{*}{ Baseline ( 0 infusion) t0 } & \multirow{2}{*}{$\begin{array}{l}<12 \text { months } \\
4-12 \text { infusions }(\mathrm{t} 1-\mathrm{t} 3)\end{array}$} & \multicolumn{2}{|l|}{$>12$ months } \\
\hline & & & 13-24 infusions (t4) & $>24$ infusions (t5) \\
\hline $\mathrm{F} / \mathrm{M}(n)$ & $8 / 14$ & $13 / 17$ & $17 / 5$ & $9 / 2$ \\
\hline Total & 22 & 30 & 22 & 11 \\
\hline STRATIFY JCV $\mathrm{JC}^{\mathbb{B} \mathrm{a}}+/-$ t0 & $4 / 18$ & $5 / 25$ & & \\
\hline STRATIFY JCV ${ }^{\mathbb{B} a}+/-$ t3 & - & $13 / 17$ & $6 / 16$ & $3 / 8$ \\
\hline Mean age ( \pm stand. dev.) & $30.6( \pm 6.8)$ & $35( \pm 8.4)$ & $38.2( \pm 7.6)$ & $39.7( \pm 10.6)$ \\
\hline Mean of months of disease ( \pm stand. dev.) & $84( \pm 85.7)$ & $107( \pm 89.7)$ & $100( \pm 79.2)$ & $75.6( \pm 44.9)$ \\
\hline Mean EDSS ${ }^{\mathrm{b}}$ ( \pm stand. dev.) & $1.9( \pm 1.3)$ & $2.1( \pm 1.0)$ & $\begin{array}{l}2.2( \pm 1.1) \\
2(1-4)\end{array}$ & $\begin{array}{l}2.2( \pm 1.0) \\
2(1-4)\end{array}$ \\
\hline No therapy ${ }^{\mathrm{c}}(n)$ & 9 & 9 & 5 & 1 \\
\hline Interferon $^{c}(n)$ & 13 & 18 & 12 & 8 \\
\hline Glatimer acetate $^{\mathrm{c}}(n)$ & - & 3 & 5 & 2 \\
\hline
\end{tabular}

$F$ female, $M$ male, $n$ number of patients, stand. dev. standard deviation

${ }^{\text {a }}$ STRATIFY JCV ${ }^{\circledR}$ : two-step virus-like particle-based enzyme-linked immunosorbent assay (ELISA) was performed at $\mathrm{t} 0$ and $\mathrm{t} 3$ ( 1 year of treatment), to detect specific anti-JC virus antibodies in serum of the enrolled subjects (Gorelik et al. 2010)

${ }^{b}$ EDSS: Kurtzke Expanded Disability Status Scale, with values ranging from 0 (normal neurological examination) to 10 (bedridden patient) (Kurtzke 1983 )

${ }^{\mathrm{c}}$ Therapy before starting with natalizumab treatment

$112.4 \pm 100.3$; mean $\mathrm{EDSS} \pm$ stand. dev. $1.9 \pm 1.3$ ) have been monitored during the first year of treatment with natalizumab (follow-up $<12$ months) as follows: 1 sample of whole blood in EDTA and 1 tube of urine have been collected after $4(\mathrm{t} 1), 8(\mathrm{t} 2)$, and 12 (t3) infusions of natalizumab, respectively. Forty-five samples of whole blood in EDTA and 45 urine samples have been tested (Table 1).

- In addition, 18 whole blood samples in EDTA (4 collected at $\mathrm{t} 1,4$ at $\mathrm{t} 2$, and 10 at $\mathrm{t} 3$ ) and 14 urine samples (3 collected at $\mathrm{t} 1,3$ at $\mathrm{t} 2$, and 8 at $\mathrm{t} 3$ ) have been collected from other 15 patients with RRMS with the number of infusions ranging from 4 to 12 ( $<12$ months) (Table 1).

- Finally, 38 samples of whole blood in EDTA and 34 urine samples were collected from 22 patients with RRMS (mean age \pm stand. dev. 38.2 \pm 7.6 ; mean months of illness \pm stand. dev. $100 \pm 79.2$; mean $E D S S \pm$ stand. dev. $2.2 \pm 1.1$ ) with the number of infusions ranging from 13 to 24 ( $t 4)$. Moreover, 18 samples of whole blood in EDTA and 14 urine samples have been collected from 11 patients with RRMS (mean age \pm stand. dev. $39.7 \pm 10.6$; mean months of illness \pm stand. dev. 75.6 \pm 44.9 ; EDSS mean \pm stand. dev. $2.2 \pm 1.0)$ with the number of infusions higher than 24 (t5) (>12 months) (Table 1).

All patients satisfied the Italian Agency of Drug criteria for natalizumab treatment (AIFA 2010). The therapeutic program consisted of $300 \mathrm{mg}$ intravenous (IV), infused over $1 \mathrm{~h}$, every month.
After the activation of the STRATIFY JCV ${ }^{\circledR}$ service, supported by Biogen Idec, the assessment of specific anti-JC virus antibodies in serum of the enrolled subjects was performed at t0 and $\mathrm{t} 3$ (Gorelik et al. 2010).

At each follow-up visit, disease activity has been assessed by the Kurtzke Expanded Disability Status Scale (EDSS), with values ranging from 0 (normal neurological examination) to 10 (bedridden patient). EDSS is a standardized composite neurological examination, developed for multiple sclerosis clinical research (Kurtzke 1983). The magnetic resonance imaging (MRI) has been performed at the beginning of therapy and eventually during treatment, depending on the clinical course of each patient. Finally, the lumbar puncture has been performed only in the case of neuro-radiological or clinical alterations in the presence of JCV replication in plasma or peripheral blood mononuclear cells (PBMCs). Each patient, properly informed, has signed informed consent, in order to take part in the study.

\section{DNA extraction}

DNA has been extracted from a total of 141 plasma, 129 urine, and 141 PBMC samples collected at the specified time-points. DNA extraction has been conducted on $500 \mu \mathrm{L}$ of urine sample using the DNeasy ${ }^{\circledR}$ Blood \& Tissue Kit (QIAGEN, S.p.A, Italy). Blood samples have been collected in 4-mL Vacuntainer ${ }^{\circledR}$ tubes containing EDTA (BD Becton Dickinson, S.p.A, Italy) and centrifuged at $3500 \mathrm{rpm}$ for 10 min and DNA was extracted from $200 \mu \mathrm{L}$ of plasma by the DNeasy ${ }^{\circledR}$ Blood \& Tissue Kit (QIAGEN, S.p.A, Milan, 
Italy). Peripheral blood mononuclear cells (PBMCs) were isolated from whole blood using a standard Ficoll Hypaque density gradient centrifugation (Bøyum et al. 1991). The viable leukocytes have been determined by trypan blue exclusion, and PBMC DNA extraction has been obtained on $10^{6}$ cells by the QIAmp ${ }^{\circledR}$ DNA Blood Kit (QIAGEN, S.p.A, Milan, Italy). All extracted DNA samples have been stored at $-20{ }^{\circ} \mathrm{C}$ until use.

\section{JCV T-Ag real-time PCR (Q-PCR)}

Q-PCR has been performed to detect and quantify the JCV genome copy numbers using a 7300 Real-Time PCR System (Applied Biosystems, USA) and following published protocol (Delbue et al. 2008). This Q-PCR was specific for a 54-bp amplicon in the JCV T antigen region. The viral load results have been reported as the mean of two positive reactions for each sample, and the JCV DNA load in urine and plasma specimens has been expressed as genome equivalents (gEq)/ milliliter of sample and as genome equivalents $(\mathrm{gEq}) / 10^{6}$ cells of sample for PBMCs. In each Q-PCR section, negative and positive controls have been considered. The positive control consisted of serial dilutions (range $10^{5}-10^{2} \mathrm{gEq} / \mathrm{mL}$ ) of a plasmid containing the entire JCV genome, used to fit a standard curve. Finally, the amount of DNA in PBMC samples has been normalized by a specific TaqMan PCR for the housekeeping gene glyceraldehyde-3-phosphate-dehydrogenase (GAPDH, accession no. J04038). Results have been considered acceptable only in the presence of GAPDH positivity (Costa et al. 2009).

\section{JCV NCCR PCR}

Two pairs of primers that anneal to invariant regions flanking the NCCR of JCV (Pietropaolo et al. 2003) have been used in a nested-PCR. BKTT1 (5'-AAG GTC CAT GAG CTC CAT GGA TTC TTC C-3') and BKTT2 (5'-CTA GGT CCC CCA AAA GTG CTA GAG CAG C-3') amplified a 724-bp DNA fragment in JCV Mad-1 (Flaegstad et al. 1991). JC1 (5'-CCT CCA CGC CCT TAC TAC TTC TGA G-3') and JC2 (5'-AGC CTG GTG ACA AGC CAA AAC AGC TCT-3') amplified an inner sequence of the first $\mathrm{PCR}$ product, generating a fragment of $308 \mathrm{bp}$ (Markowitz et al. 1993). PCR products have been analyzed on $2 \%$ agarose gels by ethidium bromide staining.

\section{JCV VP1 PCR}

A 215-bp sequence has been amplified from the viral protein 1 (VP1) gene using primers JLP-15 (5'-ACA GTG TGG CCA GAA TTC ACT ACC-3') and JLP-16 (5'-TAA AGC CTC CCC CCC AAC AGA AA-3') (Agostini et al. 2001). After denaturation at $95{ }^{\circ} \mathrm{C}$ for $9 \mathrm{~min}, 40$ cycles at $95^{\circ} \mathrm{C}$ for $40 \mathrm{~s}$, $63{ }^{\circ} \mathrm{C}$ for $40 \mathrm{~s}$, and $72{ }^{\circ} \mathrm{C}$ for $40 \mathrm{~s}$ have been concluded with a final extension at $72{ }^{\circ} \mathrm{C}$ for $7 \mathrm{~min}$. PCR products have been analyzed using $2 \%$ electrophoresis agarose gel stained by ethidium bromide (Monaco et al. 2001).

\section{Sequencing of JCV NCCR and VP1 regions}

PCR products corresponding to JCV NCCR and VP1 regions have been purified with the QIAquick PCR purification kit, according to QIAGEN protocol (Pietropaolo et al. 2003). DNA sequencing has been conducted in service (BioFab research s.r.l., Rome, Italy). All NCCR sequences were compared to the prototype Mad-1 (NCBI Reference Sequence: NC_001699.1) (Frisque et al. 1984) and archetype CY (Yogo et al. 1990), whereas the sequences obtained from amplification of the VP1 region were analyzed on the basis of single nucleotide polymorphisms (SNPs) used to classify the JCV genotypes/subtypes (Jobes et al. 2001). Sequence alignments were performed with ClustalW2 at the EMBL-EBI website using default parameters (ClustalW2 2014).

\section{Data analysis}

Data were shown as mean \pm standard deviation or medians and ranges. If the $Z$ test indicated a non-normal distribution, nonparametric tests such as Mann-Whitney $U$ test and KruskalWallis test have been used. Categorical data were analyzed by $\chi^{2}$ test and Student's $t$ test. $p$ values $<0.05$ were considered significant.

\section{Results}

\section{Evaluation of JCV-specific serum antibodies by STRA} TIFY JCV ${ }^{\circledR}$ and JCV load by Q-PCR in biological samples collected at to from 22 patients with RRMS

Twenty-two samples of whole blood in EDTA and 22 samples of urine were collected, and JCV-specific antibodies were observed in serum of 4 patients (STRATIFY JCV ${ }^{\circledR}$ positive) while the other 18 patients were tested STRATIFY JCV ${ }^{\circledR}$ negative. Among the 4 STRATIFY ${ }^{\circledR}$ JCV-positive patients, viral DNA was detected exclusively in plasma (2.84 $\log 10 \mathrm{gEq} /$ $\mathrm{mL})$ and in PBMCs $\left(2.07 \log 10 \mathrm{gEq} / 10^{6}\right.$ cells $)$ of 1 patient (Table 2). By contrast, in 18 STRATIFY JCV ${ }^{\circledR}$-negative patients, JC viruria was found in 4/18 samples with a median viral load of $4.38 \log 10 \mathrm{gEq} / \mathrm{mL}$ (range 3.48-4.58), while JC viremia was observed in $2 / 18$ patients with a median viral load of $3.02 \log 10 \mathrm{gEq} / \mathrm{mL}$ (range 2.70-3.20). Moreover, in these 18 patients, JCV DNA was detected in 2 samples of PBMCs with a median viral load of $3.42 \log 10 \mathrm{gEq} / 10^{6}$ cells (range 1.95-3.72) (Table 2). At t0, no statistically significant difference and correlation were observed between viruria and/or viremia and STRATIFY ${ }^{\circledR}$ JCV results in these patients. 
Evaluation of JC viral load by Q-PCR in biological samples of 15 RRMS patients with follow-up in the first year of treatment with natalizumab (follow-up $<12$ months)

At t0, JCV-specific antibodies were detected only in $1 / 15$ patient, while the number of STRATIFY JCV ${ }^{\circledR}$-positive patients rose to 7/15 at $\mathrm{t} 3$. Regarding the detection of JCV DNA by QPCR in urine, in samples collected at t0, JC viruria was observed in $4 / 15$ STRATIFY $\mathrm{JCV}^{\circledR}$-negative patients at $\mathrm{t} 0$. These patients developed anti-JCV antibodies during the first year of treatment with natalizumab, becoming STRATIFY $\mathrm{JCV}^{\circledR}$ positive at $\mathrm{t} 3$. The median viral load in urine samples at t0 was $4.38 \log 10 \mathrm{gEq} / \mathrm{mL}$ (range 3.48-4.58), while after 4 months of treatment with natalizumab (t1), this value was $4.11 \log 10 \mathrm{gEq} / \mathrm{mL}$ (range 2.00-6.01). At t2 (after 8 natalizumab infusions), the number of patients with JCV DNA in the urine increased from 4 to 5 , with the finding of $\mathrm{JC}$ viruria in 1 patient which resulted STRATIFY JCV ${ }^{\circledR}$ negative both at $\mathrm{t} 0$ and at $\mathrm{t} 3$. This patient subsequently became negative for JCV DNA in urine at $\mathrm{t} 3$ (after 12 natalizumab infusions). In conclusion, a persistent viruria throughout follow-up was observed in 4/15 RRMS patients. Overall, compared to $t 0$, the median viral load in the urine increased up to $5.18 \log 10 \mathrm{gEq} / \mathrm{mL}$ (range $3.77-5.65$ ) at $\mathrm{t} 2$ and up to $5.63 \log 10 \mathrm{gEq} / \mathrm{mL}$ (range 5.29-5.94) at $\mathrm{t} 3$, and this increase was statistically significant ( $p=0.05$ ) (Fig. 1).

Regarding the JCV DNA detection in plasma samples, JC viremia was found at $t 0$ in only 2 patients with a negative STRATIFY JCV ${ }^{\circledR}$ and a value of the median viral load of $2.95 \log 10 \mathrm{gEq} / \mathrm{mL}$ (range 2.70-3.21). However, these 2 patients with viremia at $\mathrm{t} 0$ were negative at $\mathrm{t} 1$, while other 2 patients (STRATIFY JCV ${ }^{\circledR}$ negative at t0 and STRATIFY $\mathrm{JCV}^{\circledR}$ positive at $\mathrm{t} 3$ ) with persistent viruria throughout the follow-up showed JCV DNA in plasma with a median viral load of $2.15 \log 10 \mathrm{gEq} / \mathrm{mL}$ (range 1.61-2.69). Finally at t2, all 15 RRMS patients were negative for JCV DNA in plasma whereas, at $\mathrm{t} 3$, only 1 patient (STRATIFY JCV ${ }^{\circledR}$ negative both at $\mathrm{t} 0$ and $\mathrm{t} 3)$ showed JCV load in plasma $(1.86 \log 10 \mathrm{gEq} / \mathrm{mL})$ and in PBMCs (1.11 log $10 \mathrm{gEq} / 10^{6}$ cells) (Fig. 1).

Regarding the PBMCs, at t0, JCV DNA was detected in PBMCs of 2 patients, STRATIFY JCV ${ }^{\circledR}$ negative at $t 0$ and STRATIFY JCV ${ }^{\circledR}$ positive t3, with a mean value of viral DNA copies of $2.82 \log 10 \mathrm{gEq} / 10^{6}$ cells (range 1.92-3.72). One of these two patients showed persistent viruria throughout the follow-up. At t1, the viral DNA was found in the PBMCs of only 1 patient $\left(1 \log 10 \mathrm{gEq} / 10^{6}\right.$ cells $)$ with viremia at the same time of sampling and persistent viruria throughout the follow-up. Finally, at $\mathrm{t} 2$, in only 1 patient was JCV DNA detected in PBMCs, with a viral load of $2.16 \log 10 \mathrm{gEq} / 10^{6}$ cells (data not shown).

Statistical analysis of these data highlighted that the median number of genome equivalents of JCV detected in urine was significantly higher than that observed in plasma $(p=0.047)$ 


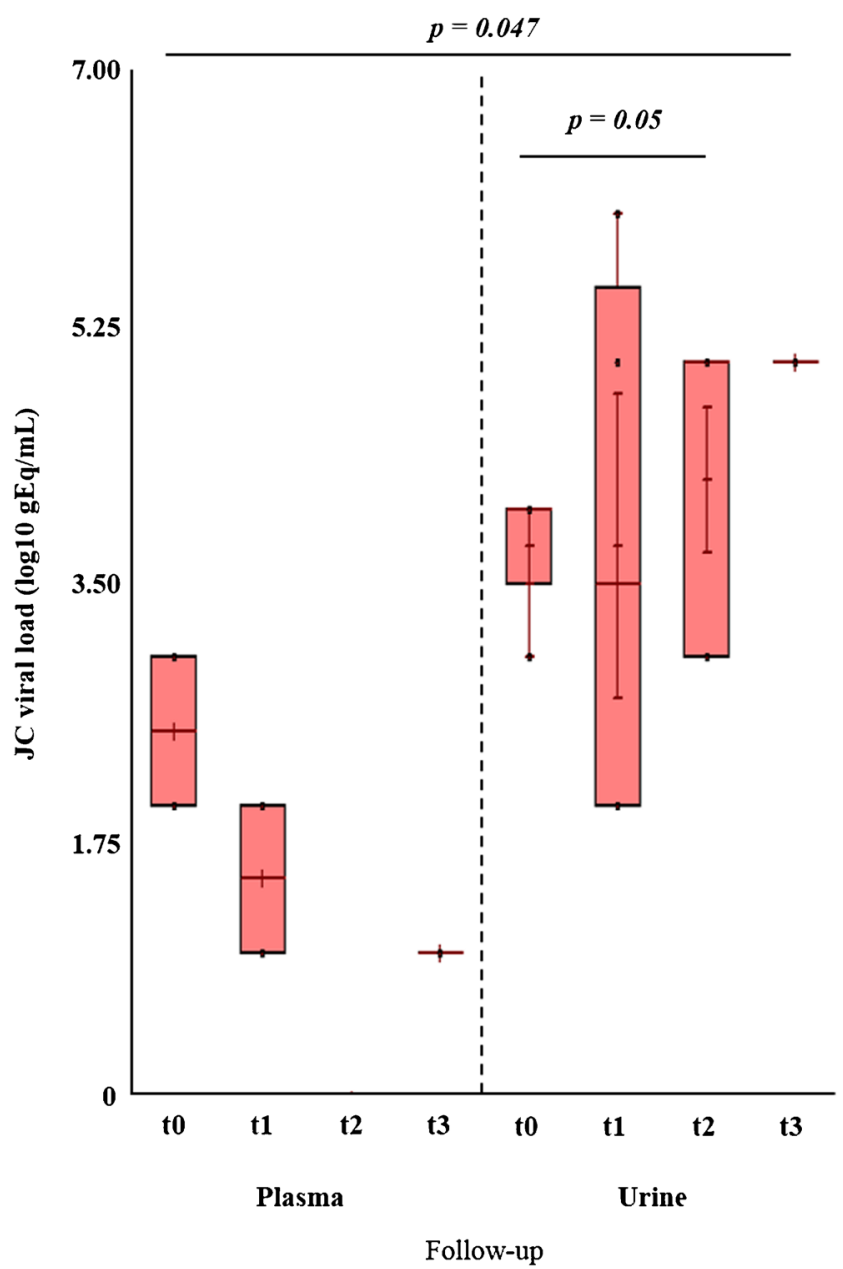

Fig. $1 \mathrm{JC}$ viremia and viruria in 15 RRSM patients during the first 12 months of natalizumab treatment (follow-up $<12$ months). Serial urine and plasma samples were performed at t0 (baseline: 0 natalizumab infusions) and every 4 months for 1 year (t1: 4 infusions; t2: 8 infusions; t3: 12 infusions). There was no statistically significant difference between $\mathrm{JC}$ viremia values recorded at $\mathrm{t} 0$ and the other values observed at each time of follow-up. On the other hand, JC viruria values observed at $\mathrm{t} 2$ were significantly higher than those observed at t 0 . Finally, at each time of follow-up, the JC viremia values were always significantly lower with respect to the JC viruria values. Statistical analysis was performed using nonparametric tests and significance was set for a $p$ value $<0.05$

(Fig. 1) and in PBMC ( $p=0.029)$ (data not shown). Finally, $2 / 15$ patients did not perform two natalizumab infusions, due to a concomitant urinary infection by Escherichia coli and a clinically worsening of RRMS with a positive STRATIFY $\mathrm{JCV}^{\circledR}$ at $\mathrm{t}$.

\section{Evaluation of JC viral load by Q-PCR in biological samples of 30 RRMS patients with the number of natalizumab infusions ranging from 4 to 12 ( $<12$ months)}

In addition to the 15 patients described above, in this cohort were also enrolled another 15 patients with the mean number of infusions between 4 and 12 ( $<12$ months). From these 15 patients, 18 whole blood samples in EDTA (4 obtained at t1, 4 at $\mathrm{t} 2$, and 10 at $\mathrm{t} 3$ ) and 14 urine samples ( 3 obtained at $\mathrm{t} 1,3$ at $\mathrm{t} 2$, and 8 at $\mathrm{t} 3$ ) were collected and the JC viral load was assessed by q-PCR. Regarding the blood samples, the results showed that all 18 plasma samples were negative for viral DNA, whereas only 1/18 PBMC sample, obtained from a STRATIFY JCV ${ }^{\circledR}$-positive patient at $\mathrm{t} 3$, showed a JC viral load of $1.95 \log 10 \mathrm{gEq} / 10^{6}$ cells. On the other hand, concerning the 14 urine samples, in only one sample from 1 STRATIFY $\mathrm{JCV}^{\circledR}$-negative patient at $\mathrm{t} 3$ was JC viruria observed with a viral load value of 6.04 $\log 10 \mathrm{gEq} / 10^{6}$ cells.

Among the 59 urine samples collected in this cohort, 45 belonged to the 15 RRMS patients with a complete follow-up in the first year of natalizumab treatment and 14 belonged to 15 RRMS patients with the number of natalizumab infusions ranging from 4 to 12 ( $<12$ months). The results obtained by QPCR showed that $14 / 59$ urine samples were positive to the JCV DNA and 12 of these 14 positive urine samples were collected from 4 patients with a negative STRATIFY $\mathrm{JCV}^{\circledR}$ at $\mathrm{t} 0$ and a positive STRATIFY $\mathrm{JCV}^{\circledR}$ at $\mathrm{t} 3$. The median value of these 12 samples with $\mathrm{JC}$ viruria was $5.33 \log 10 \mathrm{gEq} / \mathrm{mL}$ (range 2-6.01). In the remaining 2 urine samples, taken from two patients with a negative STRATIFY JCV ${ }^{\circledR}$ both at $\mathrm{t} 0$ and $\mathrm{t} 3$, the mean value of the JC viral load was $5.74 \log 10 \mathrm{gEq} / \mathrm{mL}$ (range 3.77-6.04) (Table 3).

Regarding the whole blood in EDTA samples, 63 plasma samples and 63 PBMC samples were collected. 3/63 plasma and 4/63 PBMC samples resulted JCV DNA positive. In particular, the mean $\mathrm{JC}$ viremia was $2.42 \log 10 \mathrm{gEq} / \mathrm{mL}$ (range 1.61-2.69) in 2 plasma samples collected from 2 patients with a positive STRATIFY JCV ${ }^{\circledR}$ at $\mathrm{t} 3$ and a persistent JC viruria during the first year of natalizumab treatment. Moreover, a third patient, with negative STRATIFY JCV ${ }^{\circledR}$ at $\mathrm{t} 0$ and $\mathrm{t}$, showed JCV DNA in both plasma $(1.86 \log 10 \mathrm{gEq} / \mathrm{mL})$ and PBMCs $\left(1.11 \log 10 \mathrm{gEq} / 10^{6}\right.$ cells) (Table 3$)$. Finally, in 3 PBMC samples taken from three patients, with a positive STRATIFY JCV ${ }^{\circledR}$ at $\mathrm{t} 3$, a median value of $1.95 \log 10 \mathrm{gEq} /$ $10^{6}$ cells was quantified (Table 3 ).

The statistical analysis, performed by the $\chi^{2}$ test, has allowed verification of a statistically significant association between the number of JCV DNA-positive urine samples and a positive STRATIFY JCV ${ }^{\circledR}$ at t3 with respect to the number of JCV DNA-positive urine samples and a negative STRATIFY $\mathrm{JCV}^{\mathbb{B}}$ at $\mathrm{t} 3(p=0.0006)$. A relative risk (RR) of viral reactivation with urinary shedding equal to 2.57 (95\% CI 1.61-4.09) was also estimated (Table 3). Therefore, the analysis of results allowed us to conclude that the detection of JC viruria by Q-PCR may represent a predictor of JCV reactivation in the first year of natalizumab treatment. 


\section{Evaluation of JC viral load by Q-PCR in biological samples of RRMS patients with the number of natalizumab infusions $>12$ (>12 months)}

In this cohort were enrolled 22 patients with the number of natalizumab infusions ranging from 13 to 24 (t4) and 11 patients with the number of natalizumab infusions $>24(\mathrm{t} 5)$ (Table 1). Thirty-eight samples of whole blood in EDTA and 34 urine samples were collected from the 22 patients at $t 4$. Finally, 18 samples of whole blood in EDTA and 14 urine samples were collected from the 11 patients at 5 listed above. In these two groups of patients, there was no statistically significant difference or correlation between the clinical and demographic data, the results of JCV DNA detection in the different biological samples, and the outcomes of STRA TIFY JCV ${ }^{\circledR}$. Therefore, all results were related to the cohort of RRMS patients with the number of natalizumab infusions greater than 12. It was important to note that 6 patients (1 patient with a positive STRATIFY JCV ${ }^{\circledR}$ at $\mathrm{t} 3$ and 5 patients with a negative STRATIFY JCV ${ }^{\circledR}$ at $\mathrm{t} 3$ ) underwent sample collection at both $t 4$ and $t 5$. Therefore, the total number of patients with more than 13 natalizumab infusions was 27 . From these 27 patients, 48 urine, 56 plasma, and 56 PBMC samples were collected. $8 / 48$ urine samples (median JC viruria $5.11 \log 10 \mathrm{gEq} / \mathrm{mL}$; range 2.94-6.67), 9/56 plasma samples (median JC viremia $3.01 \log 10 \mathrm{gEq} / \mathrm{mL}$; range 1.52-4.72), and 6/56 PBMC samples (median copies number 2.39 $\log 10 \mathrm{gEq} / 10^{6}$ cells; range $1.48-4.11$ ) were positive for JCV DNA These data are summarized in Table 4.

Comparison of JC viremia and viruria in RRMS patients with infusion number equal to 0 (t0: baseline), ranging from 4 to 12 ( $<12$ months) and $>12$ (>12 months)

Comparing the values of JC viruria and viremia $(\log 10 \mathrm{gEq} /$ $\mathrm{mL}$ ) obtained from 22 RRMS patients at t0, 30 RRMS patients treated with natalizumab for less than 12 months, and 27 RRMS patients treated for more than 12 months, it was observed that the median values of JC viremia were always lower than that of JC viruria $(p=0.001)$ (Table 5 and Fig. 2). In addition, it was assessed that patients treated with natalizumab for more than 12 months had a relative risk of 1.71 to develop JC viremia with respect to patients treated with less than 12 months $(p=0.04)$ (Table 5).

\section{Sequence analysis of JCV NCCR and VP1 in biological samples positive for viral DNA}

The sequence analysis of JCV NCCR in biological samples positive for viral DNA was carried out by direct sequencing of PCR products. In the group of RRMS patients treated with natalizumab for less than 12 months ( $<12$ months) was found an archetype CY-like structural organization of NCCR, with 


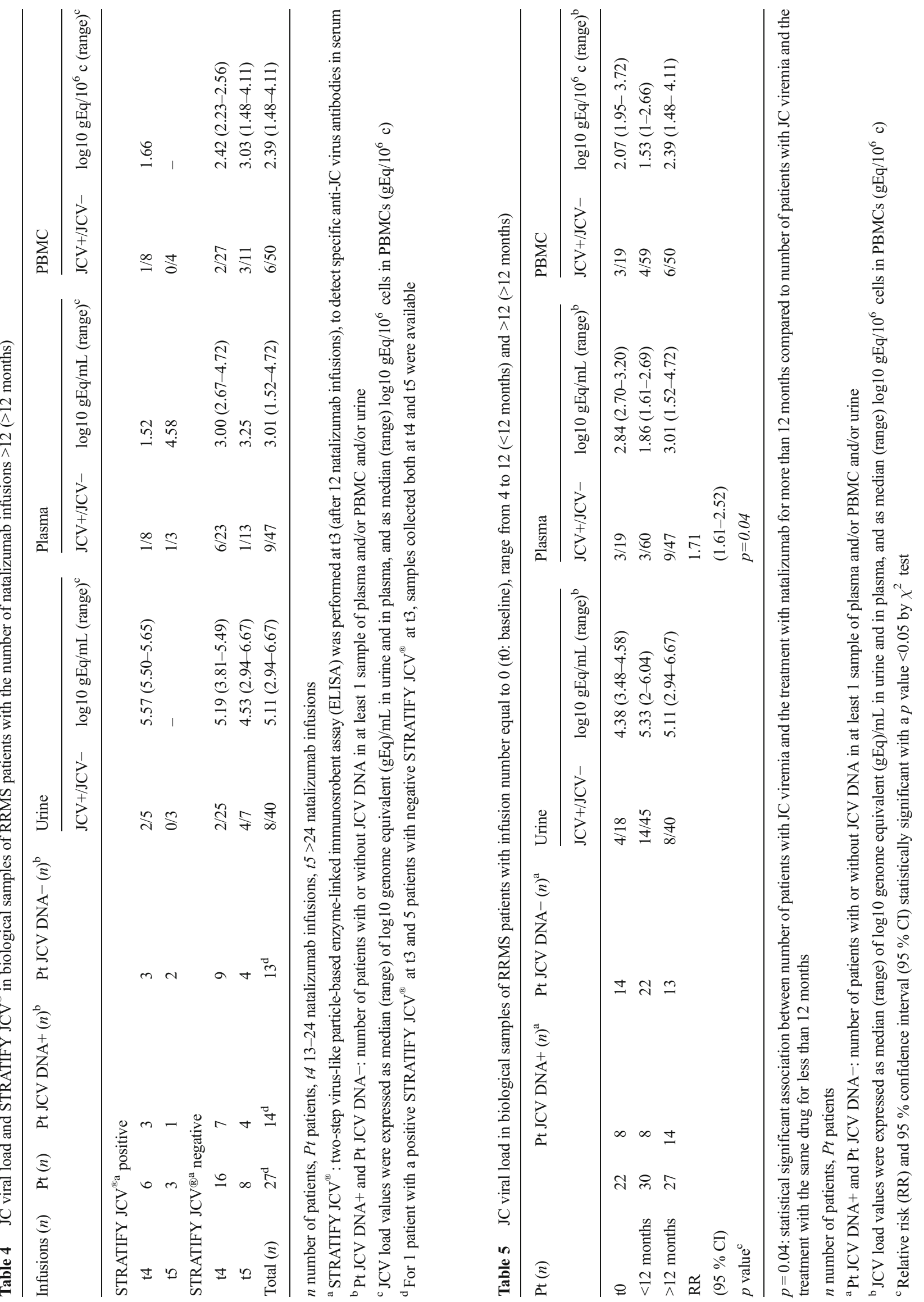


Fig. 2 JC viremia and viruria in 22 RRMS patients with the infusion number equal to $0(\mathrm{t} 0)$, 30 RRMS patients treated with natalizumab for less than 12 months ( $<12$ months), and 27 RRMS patients treated for more than 12 months ( $>12$ months). The values of JC viremia were always significantly lower than those of JC viruria in each group of RRMS patients analyzed. All the information related to JCV load values is reported in Table 5. Statistical analysis was performed using non-parametric tests and the significance fixed for a $p$ value $<0.05$

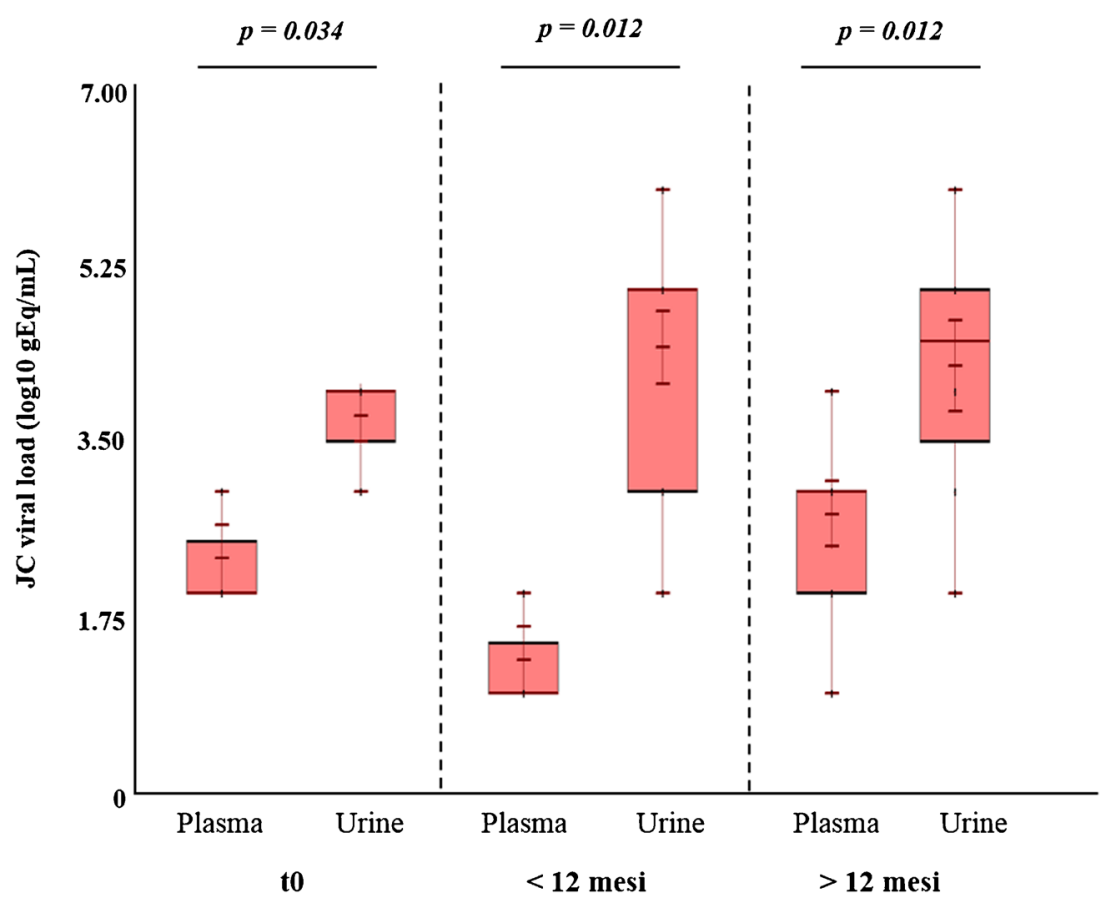

Finally, in RRMS patients treated with natalizumab for more than 12 months (>12 months), an archetype CY-like structural organization of NCCR, with the 217 G to A nucleotide transition in box F, was found in all biological samples analyzed, with the exception of a sequence that presented an archetype CY-like organization characterized by the $37 \mathrm{~T}$ to $\mathrm{G}$ nucleotide transversion within the binding site for the cellular transcription factor Spi-B in box B and the $217 \mathrm{G}$ to A nucleotide transition in box F (Fig. 3). This sequence was found in the PBMC sample of a patient with positive STRATIFY JCV ${ }^{\circledR}$ at $\mathrm{t} 3$.

Regarding the sequence analysis of JCV VP1, in order to determine the viral genotype/subtype, in RRMS patients treated with natalizumab for less than 12 months ( $<12$ months), genotypes 1A (40\%) and 1B (50\%) were observed. Moreover, in the patient with a positive STRATIFY JCV ${ }^{\circledR}$ and rearranged NCCR in the urine, a JCV co-infection by genotypes $1 \mathrm{~A}$ and $2 \mathrm{C}$ was observed, while only genotype $1 \mathrm{~A}$ was found in the plasma of the same patient. In the cohort of patients with RRMS treated with natalizumab for more than 12 months (>12 months), genotypes 1A (31\%), 1B (46\%), and $4(23 \%)$ were always found in the urine and/or plasma positive for JCV DNA.

\section{Discussion}

The pathogenesis of natalizumab-associated PML onset is still poorly understood, and viral and/or host factors are not available in order to detect those natalizumab-treated patients with high risk to develop PML (Mancuso et al. 2012). A clear association between JC viremia and/or viruria and PML has 


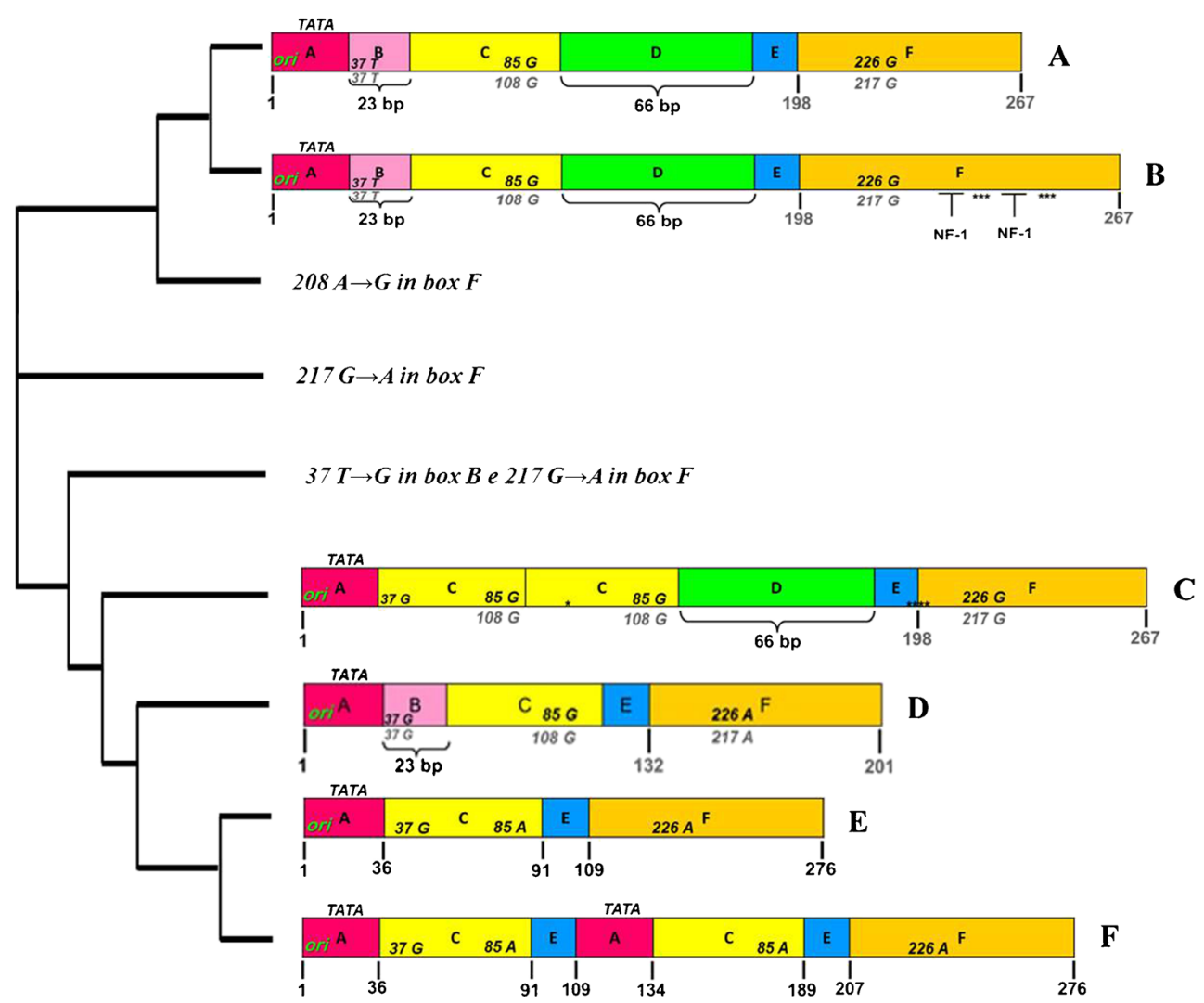

Fig. 3 Sequences of JCV NCCR found in biological samples of RRMS patients treated with natalizumab. The nucleotide sequences of JCV NCCR were shown from the core of the replication origin (ori) up to the start codon of the gene leader (agnoprotein) of the late viral genes. In $A$, the nucleotide numbering of the archetype $\mathrm{CY}$ sequence, isolated from Yogo and colleagues in 1990, is shown in bold gray. In $F$, the nucleotide numbering was based on the NCCR sequence of the PMLassociated variant Mad-1, sequenced by Frisque and colleagues in 1984, and the nucleotide number is indicated in bold black. In $B$, the NCCR sequence was characterized by a duplication of cellular transcription factor NF-1 binding site in box F, with loss of the $217 \mathrm{G}$ to $\mathrm{A}(\mathrm{G} \rightarrow \mathrm{A})$ nucleotide transition in the same box. It was found in 4 JCV DNApositive urine samples collected at $\mathrm{t} 0, \mathrm{t} 1, \mathrm{t} 2$, and $\mathrm{t} 3$, respectively, from 1 patient with positive STRATIFY JCV ${ }^{\circledR}$. In $C$, a rearranged NCCR was

not been also established. In order to stratify the risk of PML onset among RRMS patients treated with natalizumab, a new ELISA assay for the detection of JCV-specific antibodies (JCV STRATIFY ${ }^{\circledR}$ ) has been designed. Although this method was extremely sensitive, some authors have found a falsenegative rate equal to $2.5 \%$ in a cohort of RRMS patients with viral DNA in the urine but no JCV-specific antibodies in serum (Gorelik et al. 2010).

In this study, the data obtained from STRATIFY JCV were not always correlated with those obtained by Q-PCR: in fact, the presence of viral DNA in urine samples at baseline $(\mathrm{t} 0)$ preceded the antibody detection in serum samples after 12 natalizumab infusions (negative STRATIFY JCV ${ }^{\circledR}$ at $\mathrm{t} 0$ and positive STRATIFY JCV ${ }^{\mathbb{B}}$ at $\mathrm{t} 3$ ). These data were in agreement with those of other studies reported in the literature, which showed an asymptomatic JCV reactivation at the level reported, characterized by the deletion of box B with a $\mathrm{T}$ to $\mathrm{G}$ nucleotide transversion within the cellular transcription factor Spi-B binding site, the duplication of box $\mathrm{C}$, and the presence of box D. It was isolated from PBMC samples of 2 RRMS patients that were STRATIFY JCV ${ }^{\circledR}$ positive after 1 year of treatment with natalizumab ( $\mathrm{t} 3$ ). In $D$, the sequence with an archetype CY-like structural organization was reported but with the deletion of box D and two characteristic point mutations: the $37 \mathrm{~T}$ to $\mathrm{G}$ $(T \rightarrow G)$ nucleotide transversion within the binding site for the cellular transcription factor Spi-B in box B and the $217 \mathrm{G}$ to A nucleotide transition in box F. Finally, in $E$, the sequence model IS is illustrated, consisting of a single sequence from $98 \mathrm{bp}$, as reported by Jensen and Major JCV NCCR organization (Jensen and Major 2001). The cladogram was performed by software ClustalW2 (Clustal-W2)

of the urinary tract in patients with RRMS treated with less than 12 natalizumab infusions (Chen et al. 2009; Sadiq et al. 2010). Therefore, as suggested by other authors (Laroni et al. 2012), the analysis of the results allowed us to conclude that in RRMS patients, the trend of JC viruria may represent a predictor of viral reactivation in the first 12 months of treatment with natalizumab also in cases where the STRATIFY JCV ${ }^{\mathbb{B}}$ has given a negative result.

Finally, the results obtained suggest that JCV replication in the urinary epithelium, with concomitant presence of JC viruria, seems not to be due to a lack of infection control by the T cells, but rather to a reduction of lymphocyte diapedesis induced by natalizumab. In fact, as already suggested by other authors, the failure of localization of T lymphocytes at the level of the infected renal epithelium seems to abolish the viral antigen presentation by APCs (Chen et al. 2009; Mancuso et al. 2012). 
Some authors have also observed a decrease in JCV-specific cell-mediated response, after in vitro stimulation of PBMC from RRMS patients with a pool of JCV VP1-specific antigen after 6 and 12 natalizumab infusions, respectively. This decrease was found to be more pronounced in JC viremic patients than in non-viremic, and these results led the authors to conclude that natalizumab has a direct negative effect on the production of IFN- $\gamma$ by JCV-specific T cells after about 1 year of treatment (12 natalizumab infusions). Therefore, the reduction of JCV-specific cellular response seems to favor the reactivation of JCV in the kidney and its subsequent diffusion in the blood (Chen et al. 2009). Moreover, data obtained from this study showed a higher prevalence of negative STRATIFY JCV ${ }^{\circledR}$ patients who develop JCV viremia following the administration of the number of infusions of natalizumab greater than 12 . Therefore, the absence of JCV-specific antibodies in these patients led us to assume that humoral immunity may not be able to keep under control the viral replication at the systemic level.

Regarding the study of NCCR sequences, in the group of RRMS patients treated with natalizumab for less than 12 months ( $<12$ months), an archetype CY-like structural organization of NCCR with $217 \mathrm{G}$ to A nucleotide transition in box $\mathrm{F}$ was found in $68 \%$ of biological samples analyzed, while in the remaining $32 \%$ analyzed sequences, rearranged NCCR were identified. In 4 urine samples collected respectively at $\mathrm{t} 0, \mathrm{t} 1, \mathrm{t} 2$, and $\mathrm{t} 3$ from 1 RRMS patient with a positive STRATIFY JCV ${ }^{\circledR}$ at $\mathrm{t} 3$, a sequence of NCCR, characterized by a duplication of the binding site for the cellular transcription factor NF-1 in box F, was found without the $217 \mathrm{G}$ to A nucleotide transition in the same box. Finally, in 2 PBMC samples, belonging to 2 different RRMS patients with positive STRATIFY JCV ${ }^{\circledR}$ at $\mathrm{t}$, a rearranged NCCR was found and it was characterized by the deletion of box $\mathrm{B}$, the $37 \mathrm{~T}$ to $\mathrm{G}$ nucleotide transversion within the binding site for the cellular transcription factor Spi-B, the duplication of box C, and the presence of box D. In particular, the last described sequence showed that rearranged viral strains might reverse into the bloodstream throughout latency in PBMCs. In particular, this rearranged sequence showed a deletion of the $\mathrm{B}$ box with $37 \mathrm{~T}$ to $\mathrm{G}$ nucleotide transversion in the hematopoietic transcription factor Spi-B binding site, duplications of box C, and the CRE element binding site. This rearrangement was similar to the sequence of neurotropic variants found in patients with PML by some authors (Ferenczy et al. 2012; Marzocchetti et al. 2007). In particular, the potential neurovirulence of this rearranged sequence was conferred by the repeat of the CRE element binding site in box C, a specific enhancer of JCV replication in glial cells (Kumar et al. 1996), and by formation of the high-affinity binding site for the transcription factor hematopoietic Spi-B, the expression of which is elevated in hematopoietic cell lines (CD34+ cells and B cells), where the JC virus establishes latency (Lindberg et al. 2008; Major 2010). In addition, as widely described in the literature, it seems that the use of natalizumab may promote the mobilization of CD34+ cells and B cells infected with JCV. Therefore, these cells may be considered carriers of the virus to the CNS (Major 2009; Neumann et al. 2009). In particular, the $37 \mathrm{~T}$ to $\mathrm{G}$ transversion nucleotide transforms the typical binding site for the cellular factor Spi-B (5'-AAAAGGGAAGGTA-3') of the non-pathogenic JCV variant (archetype $\mathrm{CY}$ ) in that characteristic of PML-associated JCV variant Mad-1 (5'-AAAA GGGAAGGGA-3'), and this could result in viral replication and NCCR rearrangement (Marshall et al. 2012). However, further studies are needed to understand what are the cellular pathways involved in the expression of the hematopoietic transcription factor Spi-B and how these pathways are regulated by the production of specific cytokines involved in the control of viral infection (Bellizzi et al. 2013).

Finally, the detection of the $217 \mathrm{G}$ to T nucleotide transition in box $\mathrm{F}$ at the level of the binding site for the cellular transcription factor NF-1 is in agreement with literature data, which reported this point mutation in the European JCV strains (Agostini et al. 1996). However, in 4 urine samples collected respectively at $\mathrm{t} 0, \mathrm{t} 1, \mathrm{t} 2$, and $\mathrm{t} 3$ from 1 RRMS patient with a positive STRATIFY JCV ${ }^{\circledR}$ at $\mathrm{t} 3$, a sequence of NCCR, characterized by a duplication of the binding site for the cellular transcription factor NF-1 in box F, was found without the $217 \mathrm{G}$ to A nucleotide transition in the same box. It was noted that NF-1 increased the expression of early and late genes of JCV in glial cells, permissive to viral replication (Monaco et al. 2001; Shinohara et al. 1997). Moreover, the tandem repeated NF-1 binding sites on JCV NCCR could be considered determinants of specificity for glial cells and therefore determinants of neurotropism. Therefore, the duplication of the binding site for the cellular transcription factor NF-1 in box F, observed in NCCR isolated from urine samples, suggests that the natalizumab-induced alterations of immunosurveillance could determine a selective pressure on $\mathrm{JCV}$ variants with determinants of neurotropism and increased neurovirulence.

Sequence analysis of the viral VP1 was performed on samples of urine and plasma in order to determine the genotypes of JCV circulating in patients treated with natalizumab. The prevalence of genotypes $1 \mathrm{~A}$ and $1 \mathrm{~B}$, most commonly found in European populations (Agostini et al. 2001), was observed. In the two patients with RRMS who, after 1 year of treatment with natalizumab had rearranged sequences in PBMC of the NCCR, were found genotype $1 \mathrm{~A}$ and $1 \mathrm{~B}$, respectively.

In conclusion, although it has not been possible to identify a real correlation between the presence of variants neurovirulent and treatment with natalizumab, this study showed that during the spread of the virus into the host, you go to select particular sequences of the NCCR of JCV and that treatment with monoclonal antibody seems to have a role in the selection of these variants. However, it remains unclear what the viral and host factors are behind this selection process. 


\section{Conclusion}

In conclusion, for a more accurate stratification of the risk of PML in patients treated with natalizumab, the JC viruria assay would seem to be useful in identifying those patients with JCV-specific humoral response that is not yet detectable. In addition, the results of this study show the importance of the analysis of rearrangements of the NCCR of JCV. Currently, we do not know the significance of our finding regarding JCV NCCR analysis and, therefore, further investigation is warranted Moreover, the study of the molecular mechanisms involved in cell latency and reactivation of JCV in peripheral blood cells is of substantial importance in order to identify the missing pieces in the puzzle of the pathogenesis of PML. It is therefore essential to focus attention on cellular pathways, finely regulated by the host's immune system, leading to reactivation of the virus under conditions of immunosuppression, since the treatment of PML with anti-viral drugs has proved to be ineffective.

Acknowledgments The authors thank Monica Mischitelli, Ph.D., for her critical advice and comments. This work was supported by the MIUR grant. Anna Bellizzi was supported by post-doctoral fellowship "Teresa Ariaudo 2013" dispensed by Institute Pasteur Cenci-Bolognetti Foundation.

Conflict of interest The authors declare that they have no competing interests.

Open Access This article is distributed under the terms of the Creative Commons Attribution 4.0 International License (http:// creativecommons.org/licenses/by/4.0/), which permits unrestricted use, distribution, and reproduction in any medium, provided you give appropriate credit to the original author(s) and the source, provide a link to the Creative Commons license, and indicate if changes were made.

\section{References}

Agostini HT, Ryschkewitsch CF, Stoner GL (1996) Genotype profile of human polyomavirus JC excreted in urine of immunocompetent individuals. J Clin Microbiol 34:159-164

Agostini HT, Deckhut A, Jobes DV, Girones R, Schlunck G, Prost MG, Frias C, Pérez-Trallero E, Ryschkewitsch CF, Stoner GL (2001) Genotypes of JC virus in East, Central and Southwest Europe. J Gen Virol 82:1221-1331

AIFA (2010) Nota informativa sul Tysabri ${ }^{\circledR}$ In: AIFA - Agenzia Italiana del Farmaco. Available via DIALOG. http://www.agenziafarmaco. gov.it/it/content/nota-informativa-importante-su-tysabrinatalizumab-18022010. Accessed 17 Oct 2014

Andreoletti L, Lescieux A, Lambert V, Si-Mohamed A, Matta M, Wattré P, Belec L (2002) Semiquantitative detection of JCV-DNA in peripheral blood leukocytes from HIV-1-infected patients with or without progressive multifocal leukoencephalopathy. J Med Virol 66:1-

Bellizzi A, Anzivino E, Rodio DM, Palamara AT, Nencioni L, Pietropaolo V (2013) New insights on human polyomavirus JC and pathogenesis of progressive multifocal leukoencephalopathy. Clin Dev Immunol. doi:10.1155/2013/839719
Berger JR, Houff S (2009) Opportunistic infections and other risks with newer multiple sclerosis therapies. Ann Neurol 65:367-377

Bloomgren G, Richman S, Hotermans C, Subramanyam M, Goelz S, Natarajan A, Lee S, Plavina T, Scanlon JV, Sandrock A, Bozic C (2012) Risk of natalizumab-associated progressive multifocal leukoencephalopathy. N Engl J Med 366:1870-1880

Bøyum A, Løvhaug D, Tresland L, Nordlie EM (1991) Separation of leucocytes: improved cell purity by fine adjustments of gradient medium density and osmolality. Scand J Immunol 34:697-712

Brew BJ, Davies NW, Cinque P, Clifford DB, Nath A (2010) Progressive multifocal leukoencephalopathy and other forms of JC virus disease. Nat Rev Neurol 6:667-679

Chen Y, Bord E, Tompkins T, Miller J, Tan CS, Kinkel RP, Stein MC, Viscidi RP, Ngo LH, Koralnik IJ (2009) Asymptomatic reactivation of JC virus in patients treated with natalizumab. N Engl J Med 361: $1067-1074$

ClustalW2 (2014) Multiple sequence alignment. Available via DIALOG. http://www.ebi.ac.uk/Tools/msa/clustalw2/. Accessed 17 Oct 2014

Coisne C, Mao W, Engelhardt B (2009) Cutting edge: natalizumab blocks adhesion but not initial contact of human T cells to the blood-brain barrier in vivo in an animal model of multiple sclerosis. J Immunol 182:5909-5913

Costa C, Bergallo M, Sidoti F, Astegiano S, Terlizzi ME, Mazzucco G, Segoloni GP, Cavallo R (2009) Polyomaviruses BK- and JC-DNA quantitation in kidney allograft biopsies. J Clin Virol 44:20-23

Delbue S, Branchetti E, Boldorini R, Vago L, Zerbi P, Veggiani C, Tremolada S, Ferrante P (2008) Presence and expression of JCV early gene large $\mathrm{T}$ antigen in the brains of immunocompromised and immunocompetent individuals. J Med Virol 80:2147-2152

Ferenczy MW, Marshall LJ, Nelson CD, Atwood WJ, Nath A, Khalili K, Major EO (2012) Molecular biology, epidemiology, and pathogenesis of progressive multifocal leukoencephalopathy, the JC virusinduced demyelinating disease of the human brain. Clin Microbiol Rev 25:471-506

Flaegstad T, Sundsfjord A, Arthur RR, Pedersen M, Traavik T, Subramani S (1991) Amplification and sequencing of the control regions of BK and JC virus from human urine by polymerase chain reaction. Virology 180:553-560

Frisque RJ, Bream GL, Cannella MT (1984) Human polyomavirus JC virus genome. J Virol 51:458-469

Gorelik L, Lerner M, Bixler S, Crossman M, Schlain B, Simon K, Pace A, Cheung A, Chen LL, Berman M, Zein F, Wilson E, Yednock T, Sandrock A, Goelz SE, Subramanyam M (2010) Anti-JC virus antibodies: implications for PML risk stratification. Ann Neurol 68: 295-303

Jensen PN, Major EO (2001) A classification scheme for human polyomavirus JCV variants based on the nucleotide sequence of the noncoding regulatory region. J Neurovirol 7:280-287

Jobes DV, Friedlaender JS, Mgone CS, Agostini HT, Koki G, Yanagihara R, Ng TCN, Chima SC, Ryschkewitsch CF, Stoner GL (2001) New $\mathrm{JC}$ virus (JCV) genotypes from papua new guinea and micronesia (type 8 and type 2E) and evolutionary analysis of 32 complete JCV genomes. Arch Virol 146:2097-2113

Kean JM, Rao S, Wang M, Garcea RL (2009) Seroepidemiology of human polyomaviruses. PLoS Pathog 5:e1000363

Kivisakk P, Healy BC, Viglietta V, Quintana FJ, Hootstein MA (2009) Natalizumab treatment is associated with peripheral sequestration of proinflammatory T cells. Neurology 72:1922-1930

Kleinschmidt-DeMasters BK, Tyler KL (2005) Progressive multifocal leukoencephalopathy complicating treatment with natalizumab and interferon beta-1a for multiple sclerosis. N Engl J Med 353:369-374

Kumar KU, Tang SC, Pater MM, Pater A (1996) Glial and muscle embryonal carcinoma cell-specific independent regulation of expression of human JC virus early promoter by cyclic AMP response elements and adjacent nuclear factor 1 binding sites. J Med Virol 49:199-204 
Kurtzke JF (1983) Rating neurologic impairment in multiple sclerosis: an expanded disability status scale (EDSS). Neurology 33:1444-1452

Langer-Gould A, Atlas SW, Green AJ, Bollen AW, Pelletier D (2005) Progressive multifocal leukoencephalopathy in a patient treated with natalizumab. N Engl J Med 353:375-381

Laroni A, Giacomazzi CG, Grimaldi L, Gallo P, Sormani MP, Bertolotto A, McDermott JL, Gandoglia I, Martini I, Vitello G, Rinaldi F, Barzon L, Militello V, Pizzorno M, Bandini F, Capello E, Palù G, Uccelli A, Mancardi GL, Varnier OE (2012) Urinary JCV-DNA testing during natalizumab treatment may increase accuracy of PML risk stratification. J Neuroimmune Pharmacol 7:665-672

Lindberg RL, Achtnichts L, Hoffmann F, Kuhle J, Kappos L (2008) Natalizumab alters transcriptional expression profiles of blood cell subpopulations of multiple sclerosis patients. J Neuroimmunol 194: $153-164$

Major EO (2009) Reemergence of PML in natalizumab-treated patients - new cases, same concerns. N Engl J Med 361:1041-1043

Major EO (2010) Progressive multifocal leukoencephalopathy in patients on immunomodulatory therapies. Annu Rev Med 61:35-47

Mancuso R, Saresella M, Hernis A, Marventano I, Ricci C, Agostini S, Rovaris M, Caputo D, Clerici M (2012) JC virus detection and JC virus-specific immunity in natalizumab-treated multiple sclerosis patients. J Transl Med 10:248. doi:10.1186/1479-5876-10-248

Markowitz RB, Thompson HC, Mueller JF, Cohen JA, Dynan WS (1993) Incidence of BK virus and JC virus viruria in human immunodeficiency virus infected and uninfected subjects. J Infect Dis 167:1320

Marshall LJ, Major EO (2010) Molecular regulation of JC virus tropism: insights into potential therapeutic targets for progressive multifocal leukoencephalopathy. J Neuroimmune Pharmacol 5:404-417

Marshall LJ, Moore LD, Mirsky MM, Major EO (2012) JC virus promoter/enhancers contain TATA box-associated Spi-Bbinding sites that support early viral gene expression in primary astrocytes. J Gen Virol 93:651-661

Marzocchetti A, Sanguinetti M, Giambenedetto SD, Cingolani A, Fadda G, Cauda R, De Luca A (2007) Characterization of JC virus in cerebrospinal fluid from HIV-1 infected patients with progressive multifocal leukoencephalopathy: insights into viral pathogenesis and disease prognosis. J Neurovirol 13:338-346

Marzocchetti A, Tompkins T, Clifford DB, Gandhi RT, Kesari S, Berger JR, Simpson DM, Prosperi M, De Luca A, Koralnik IJ (2009) Determinants of survival in progressive multifocal leukoencephalopathy. Neurology 73:1551-1558

Monaco MC, Sabath BF, Durham LC, Major EO (2001) JC virus multiplication in human hematopoietic progenitor cells requires the NF-1 class D transcription factor. J Virol 75:9687-9695
Neumann F, Zohren F, Haas R (2009) The role of natalizumab in hematopoietic stem cell mobilization. Expert Opin Biol Ther 9:10991106

Padgett BL, Walker DL, Zu Rhein GM, Echroade RJ, Dessel BH (1971) Cultivation of papova-like virus from human brain with progressive multifocal leukoencephalopathy. Lancet 1:1257-1260

Pietropaolo V, Videtta M, Fioriti D, Mischitelli M, Arancio A, Orsi N, Degener AM (2003) Rearrangement patterns of JC virus noncoding control region from different biological samples. J Neurovirol 9:603-611

Rudick RA, O'Connor PW, Polman CH, Goodman AD, Ray SS, Griffith NM, Jurgensen SA, Gorelik L, Forrestal F, Sandrock AW, Goelz S (2010) Assessment of JC virus DNA in blood and urine from natalizumab-treated patients. Ann Neurol 68:304-310

Sadiq SA, Puccio LM, Brydon EW (2010) JCV detection in multiple sclerosis patients treated with natalizumab. J Neurol 257:954-958

Shinohara T, Nagashima K, Major EO (1997) Propagation of the human polyomavirus JCV in human neuroblastoma cell lines. Virology 228:269-277

Sørensen PS, Bertolotto A, Edan G, Giovannoni G, Gold R, Havrdova E, Kappos L, Kieseier BC, Montalban X, Olsson T (2012) Risk stratification for progressive multifocal leukoencephalopathy in patients treated with natalizumab. Mult Scler 18:143-152

Stuve O, Marra CM, Jerome KR, Cook L, Cravens PD (2006) Immune surveillance in multiple sclerosis patients treated with natalizumab. Ann Neurol 59:743-747

Tan CS, Koralnik IJ (2010) Progressive multifocal leukoencephalopathy and other disorders caused by JC virus: clinical features and pathogenesis. Lancet Neurol 9:425-437

Tan CS, Ellis LC, Wuthrich C, Ngo L, Broge TA Jr, Saint-Aubyn J, Miller JS, Koralnik IJ (2010) JC virus latency in the brain and extraneural organs of patients with and without progressive multifocal leukoencephalopathy. J Virol 84:9200-9209

TYSABRI Safety Update. (2015). Available via DIALOG https:// medinfo.biogenidec.com/medinfo/secure/pmlresource.do? resource $=$ TYSABRIPMLSafetyUpdate. Accessed Jan 2015

Van Assche G, Van Ranst M, Sciot R, Dubois B, Vermeire S, Noman M, Verbeeck J, Geboes K, Robberecht W, Rutgeerts P (2005) Progressive multifocal leukoencephalopathy after natalizumab therapy for Crohn's disease. N Engl J Med 353:362-368

Weissert R (2011) Progressive multifocal leukoencephalopathy. J Neuroimmunol 231:73-77

Yogo Y, Kitamura T, Sugimoto C, Ueki T, Aso Y, Hara K, Taguchi F (1990) Isolation of a possible archetypal JC virus DNA sequence from nonimmunocompromised individuals. J Virol 64:3139-3143

Zohren F, Toutzaris D, Klarner V, Hartung HP, Kieseier B, Haas R (2008) The monoclonal anti-VLA-4 antibody natalizumab mobilizes CD34 + hematopoietic progenitor cells in humans. Blood 111:3893-3895 